Following the discovery in the early 1960s that mitochondria contain their own DNA (mtDNA), there were two major advances, both in the 1980s: the human mtDNA sequence was published in 1981, and in 1988 the first pathogenic mtDNA mutations were identified. The floodgates were opened, and the 1990s became the decade of the mitochondrial genome. There has been a change of emphasis in the first few years of the new millennium, away from the "magic circle" of mtDNA and back to the nuclear genome. Various nuclear genes have been identified that are fundamentally important for mitochondrial homeostasis, and when these genes are disrupted, they cause autosomally inherited mitochondrial disease. Moreover, mitochondrial dysfunction plays an important role in the pathophysiology of several well established nuclear genetic disorders, such as dominant optic atrophy (mutations in OPA 1), Friedreich's ataxia (FRDA), hereditary spastic paraplegia (SPG7), and Wilson's disease (ATP7B).The next major challenge is to define the more subtle interactions between nuclear and mitochondrial genes in health and disease.

See end of article for authors' affiliations

Correspondence to: Dr P F Chinnery, Neurology, The Medical School, Newcastle upon Tyne NE2 4HH, UK; p.f.chinnery@ncl.ac.uk

Received 25 March 2003 In revised form 22 May 2003

Accepted 24 May 2003

\section{HISTORICAL INTRODUCTION}

It is over 40 years since the first human mitochondrial disease was described in a patient with non-thyroidal hypermetabolism (Luft disease). ${ }^{1}$ Although this disorder is exceptionally rare (only two cases have been described), the clinical description and biochemical studies paved the way for three decades of clinical and pathological research on patients with suspected mitochondrial disease. Patients were classified into groups based upon the pattern of clinical involvement, histological and ultrastructural abnormalities of mitochondria, and biochemical assays of mitochondrial function. It was clear that there were clinical similarities among some patients, allowing the definition of syndromes such as the Kearns-Sayre syndrome (KSS) or chronic progressive external ophthalmoplegia (CPEO), but it was recognised that there was considerable phenotypic diversity and that many patients did not fit neatly into a specific diagnostic group.

The inheritance pattern also varied. Some patients appeared to be sporadic cases, whereas others were clearly familial. It was known for some time that mitochondrial DNA (mtDNA) was maternally inherited, and while some families displayed a clear maternal inheritance pattern, others did not. There were attempts to classify based upon the number and size of mitochondria in skeletal muscle, leading to terms such as pleoconial or megaconial myopathies, ${ }^{2}$ and also on the pattern of respiratory chain involvement. There were those who wanted to subdivide suspected mitochondrial disease into discrete categories (the "splitters" ${ }^{\prime 3}$ ) and those who thought of all mitochondrial disease as a single, if wide, spectrum of disorders (the "lumpers" ${ }^{\prime 4}$ ). At this early stage it was apparent that mitochondrial disorders were a heterogeneous group-clinically, histologically, biochemically, and probably genetically.

Following the discovery in the early 1960s that mitochondria contain their own DNA (mtDNA), there were two major advances, both in the 1980s: the human mtDNA sequence was published in $1981,{ }^{6}$ and in 1988 the first pathogenic mtDNA mutations were identified..$^{78}$ The floodgates were opened, and the 1990s became the decade of the mitochondrial genome. Over 150 different pathogenic point mutations and a larger number of different rearrangements (that is, partial deletions and duplications) of mtDNA were associated with disease, ${ }^{9}$ and there were major advances in our understanding of the molecular pathophysiology. ${ }^{10}{ }^{11}$ There has been a change of emphasis in the first few years of the new millennium, away from the "magic circle" of mtDNA and back to the nuclear genome. ${ }^{12}$ Various nuclear genes have been identified that are fundamentally important for mitochondrial homeostasis, and when these genes are disrupted, they cause autosomally inherited mitochondrial disease. ${ }^{13}$ Moreover, mitochondrial dysfunction plays an important role in the pathophysiology of several well established nuclear genetic disorders, such as dominant optic atrophy (mutations in OPAl), ${ }^{14}$ Friedreich's ataxia (FRDA), ${ }^{15}$ hereditary spastic paraplegia (SPG7), ${ }^{16}$ and Wilson's disease (ATP7B) ${ }^{17}$ The next major challenge is to define the more subtle interactions between nuclear and mitochondrial genes in health and disease. It is likely that these mechanisms will have broader relevance for our understanding of many inherited and sporadic neurological disorders.

In this article we will review the basic scientific principles that underpin our understanding of mitochondrial pathology. Rather than giving a comprehensive description of mitochondrial biology, we will focus on the bare essential facts that will help the practising general neurologist to understand, identify, investigate, and manage patients with primary mitochondrial disease (by which we mean disorders that result directly from mutations either in mtDNA or in nuclear genes affecting the respiratory chain or mtDNA homeostasis). Mitochondrial abnormalities have been identified in more common sporadic neurological disorders, including Alzheimer's disease and Parkinson's disease, and they also occur as part of 


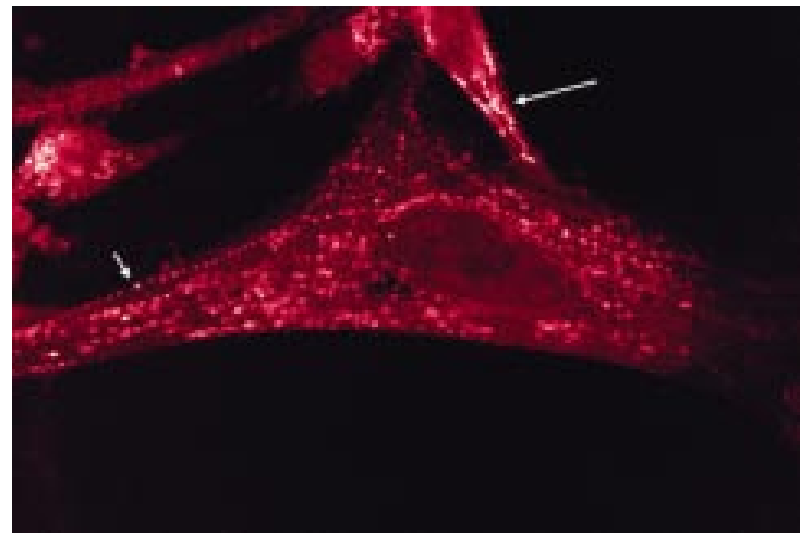

Figure 1 Human mitochondria. Scanning fluorescence confocal micrograph of a cultured human myoblasts stained with the Mitotracker, which is a fluorescent potentiometric dye taken up specifically by living mitochondria because of their membrane potential. Some mitochondria form discrete organelles (short arrow), but others form a reticulate network (long arrow).

normal aging. ${ }^{18}$ The role of these secondary mitochondrial abnormalities is uncertain, and they will be discussed in other articles in this series.

\section{WHAT ARE MITOCHONDRIA AND WHAT DO THEY DO?}

Mitochondria are a subcompartment of the cell bound by a double membrane. Although some mitochondria probably do look like the traditional cigar shaped structures that appear in standard textbooks, it is more accurate to think of them as a budding and fusing network similar to the endoplasmic reticulum (fig 1). Mitochondria are intimately involved in cellular homeostasis. Among other functions they play a part in intracellular signalling and apoptosis, intermediary metabolism, and in the metabolism of amino acids, lipids, cholesterol, steroids, and nucleotides. Apoptosis is discussed in other articles of this series and will not be considered here. Perhaps most importantly, mitochondria have a fundamental role in cellular energy metabolism. This includes fatty acid $\beta$ oxidation, the urea cycle, and the final common pathway for ATP production-the respiratory chain.

The mitochondrial respiratory chain is a group of five enzyme complexes situated on the inner mitochondrial membrane (fig 2). Each complex is composed of multiple subunits, the largest being complex I with over 40 polypeptide components. Reduced cofactors $\left(\mathrm{NADH}\right.$ and $\mathrm{FADH}_{2}$ ) generated from the intermediary metabolism of carbohydrates, proteins, and fats donate electrons to complex I and complex II. These electrons flow between the complexes down an electrochemical gradient, shuttled by complexes III and IV and by two mobile electron carriers, ubiquinone (ubiquinol, coenzyme Q10) and cytochrome $c$. The electron transfer function of complexes I-IV is accomplished through subunits harbouring prosthetic groups (for example, iron-sulphur groups in complexes I, II, and III, and haem iron in cytochrome $c$ and complex IV). The liberated energy is used by complexes I, III, and IV to pump protons $\left(\mathrm{H}^{+}\right)$out of the mitochondrial matrix into the intermembrane space. This proton gradient, which generates the bulk of the mitochondrial membrane potential (the asymmetrical distribution of ions, such as $\mathrm{Na}^{+}, \mathrm{K}^{+}$, and $\mathrm{Ca}^{2+}$, across the inner membrane makes up the "chemical" portion of the gradient), is harnessed by complex V to synthesise adenosine triphosphate (ATP) from adenosine diphosphate (ADP) and inorganic phosphate. The overall process is called oxidative phosphorylation (OXPHOS). ATP is the high energy source used for essentially all active metabolic processes within the cell, and it must be released from the mitochondrion in exchange for cytosolic ADP. This is carried out by the adenine nucleotide translocator (ANT), which has various tissue specific isoforms.

Thus the respiratory chain is an elaborate system that must respond to the energy requirements of the cell. While these requirements may be constant (for example, in hepatocytes), they may also change dramatically over short periods of time (as in skeletal muscle). We are only just beginning to understand the mechanisms that maintain and regulate a healthy respiratory chain, and it is likely that many additional unknown genetic and environmental factors will be involved.

\section{THE GENETIC BASIS OF MITOCHONDRIAL BIOGENESIS}

Two distinct genetic systems encode mitochondrial proteins: mitochondrial DNA (mtDNA) and nuclear DNA (nDNA). mtDNA is a small $16.6 \mathrm{~kb}$ circle of double stranded DNA that codes for 13 respiratory chain polypeptides and 24 nucleic acids (two ribosomal RNAs (rRNAs) and 22 transfer RNAs (tRNAs)) that are needed for intramitochondrial protein synthesis (fig 3). ${ }^{6}$ Nuclear genes code for the majority of mitochondrial respiratory chain polypeptides. ${ }^{13}$ These polypeptides are synthesised in the cytoplasm with a mitochondrial targeting sequence that directs them through the translocation machinery spanning the outer and inner membranes. The targeting sequence is then cleaved before the subunit is assembled with its counterparts on the inner mitochondrial membrane. The components of the import machinery ("TIM" and "TOM" proteins), the importation processing enzymes, and the respiratory chain assembly proteins are all the products of nuclear genes.

Nuclear genes are also important for maintaining the mitochondrial genome, including those encoding the mitochondrial DNA polymerase $\gamma(\text { POLGl })^{19}$ and products that maintain an appropriate balance of free nucleotides within the mitochondrion (TP, TK, DGK, and ANT1). ${ }^{20-23}$ A recently described gene, C10orf2, codes for a helicase-like protein called Twinkle that appears to be important for mtDNA maintenance. ${ }^{24}$ Nuclear DNA also codes for essential factors needed for intramitochondrial transcription and translation, including TFAM, TFBM1, and TFBM2. ${ }^{25}{ }^{26} \mathrm{~A}$ disruption of both nuclear and mitochondrial genes can therefore cause mitochondrial dysfunction and human disease (table 1).

\section{MITOCHONDRIAL DISEASE: GENOTYPE AND PHENOTYPE}

A neurologist who has seen a few patients with mitochondrial disease will be puzzled by a number of questions. If mitochondria are so important, why don't mitochondrial diseases affect every tissue in the body, and if primary mitochondrial disorders are all genetically determined, why do they have such a varied clinical phenotype, even within the same family? Recent advances in our understanding of the molecular pathology of mitochondrial disease have provided us with some explanations and also raised new questions.

The clinical features of mitochondrial disease have been discussed widely elsewhere, ${ }^{27-29}$ and they will not be considered in detail here (an overview is given in table 2 and fig 4).

In general terms, tissues and organs that are heavily dependent upon oxidative phosphorylation bear the brunt of the pathology. This means that neurological features are common, but cardiac, endocrine, and ophthalmological features are often prominent. Other tissues are less dependent upon sustained oxidative phosphorylation so are less likely to be involved in mitochondrial disease, but there are some notable exceptions.

While this general rule is helpful, it can only be part of the explanation. Mitochondrial disease ultimately reflects a defect of oxidative phosphorylation within a cell, but the pattern of 


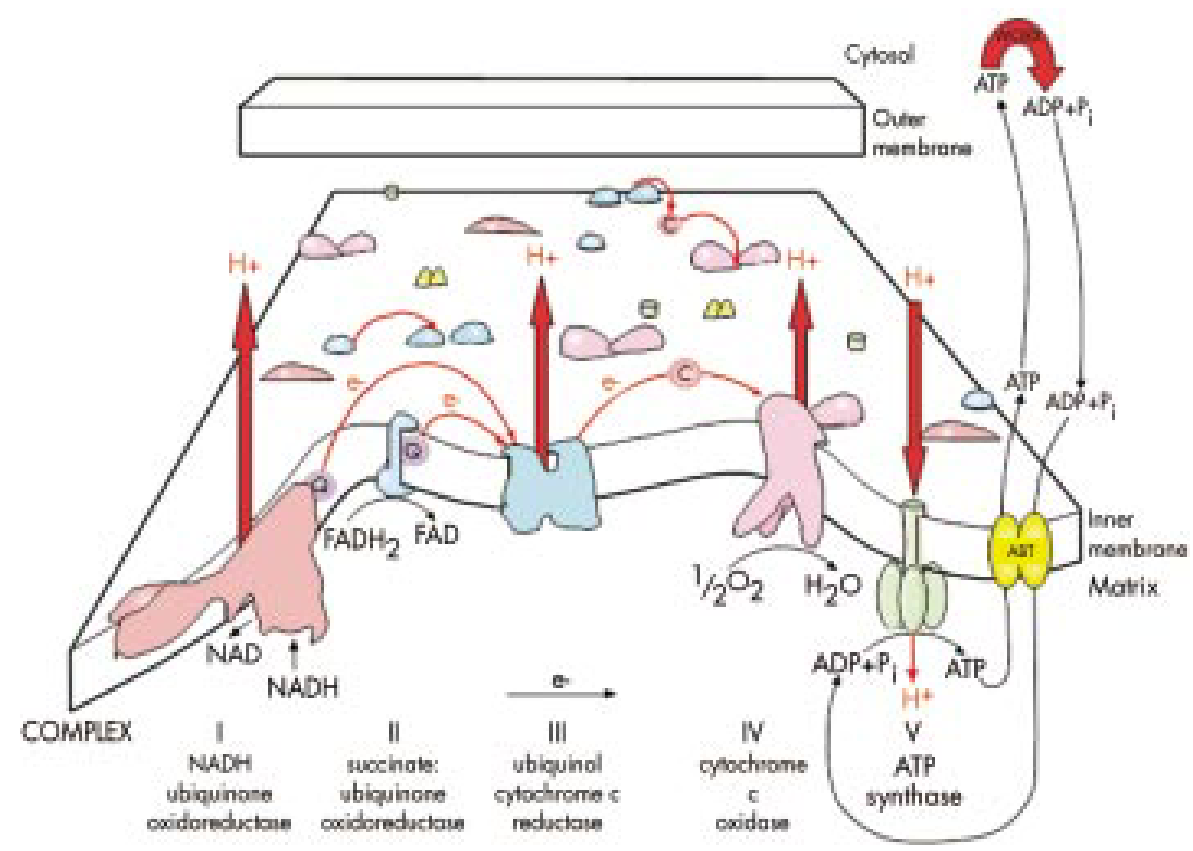

Figure 2 Schematic diagram of the respiratory chain. Reduced cofactors (NADH and $\left.F A D H_{2}\right)$ are produced from the intermediary metabolism of carbohydrates, proteins, and fats. These cofactors donate electrons to (e) to complex I (NADH-ubiquinone oxidoreductase) and complex II (succinate-ubiquinone oxidoreductase). These electrons flow between the complexes down an electrochemical gradient (black arrow), shuttled by ubiquinone (Q) and cytochrome $c$ (C) involving complex III (ubiquinol-cytochrome c oxidase reductase) and complex IV (cytochrome $c$ oxidase, or COX). Complex IV donates an electron to oxygen which results in the formation of water. Protons $\left(\mathrm{H}^{+}\right)$are pumped from the mitochondrial matrix into the intermembrane space (red arrows). This proton gradient generates the mitochondrial membrane potential which is harnessed by complex $\mathrm{V}$ to synthesise adenosine triphosphate (ATP) from adenosine diphosphate (ADP) and inorganic phosphate (Pi). ANT, adenine nucleotide translocator, which exchanges ADP for ATP across the mitochondrial membrane.

cellular involvement will determine the clinical features of the disease. On the one hand, there must be common mechanisms explaining why patients with mutations in nDNA and mtDNA can have a similar clinical phenotype (for example, clinically indistinguishable Leigh syndrome can be caused by mutations both in the nuclear COX assembly gene SURFl and the mtDNA ATPase 6 gene $\left.^{30}{ }^{31}\right)$. On the other hand, there must be different mechanisms to explain why the same genetic defect can cause very different clinical phenotypes (for example, the A3243G mtDNA mutation in the tRNA ${ }^{\text {Leu(UUR) }}$ gene can present with classical MELAS (mitochondrial encephalomyopathy with lactic acidosis and stroke-like episodes), with CPEO, or with diabetes and deafness $\mathrm{s}^{32-34}$ ). It is also puzzling that many mitochondrial disorders affect multiple organ systems, whereas others have a highly stereotyped and organ specific phenotype (such as Leber hereditary optic neuropathy and aminoglycoside induced deafness). ${ }^{35}$ Nuclear genetic mechanisms have been discussed in the preceding articles in this series, so in this article we will concentrate on mitochondrial genetic factors.

\section{MITOCHONDRIAL GENETIC FACTORS}

mtDNA has unusual properties that are important for our understanding of mitochondrial disease caused by mtDNA mutations.

\section{Heteroplasmy and the threshold effect}

While most human cells contain two copies of nuclear DNA, they contain many more copies of mtDNA (from 1000 to 100000 , depending on the cell type). These are all identical in a healthy individual at birth (homoplasmy). By contrast, patients harbouring pathogenic mtDNA defects often have a mixture of mutated and wild-type mtDNA (heteroplasmy). ${ }^{30}$ The percentage of mutated mtDNA can vary widely among different patients, and also from organ to organ, and even between cells within the same individual. In vitro studies using "transmitochondrial cytoplasmic hybrid (cybrid)" cells ${ }^{37}$ containing different amounts of mutated mtDNA have shown that most mtDNA mutations are highly recessive. In other words, the cells were able to tolerate high percentage levels of mutated mtDNA (typically $70-90 \%$ ) before they developed a biochemical respiratory chain defect. The precise threshold for biochemical expression varies from mutation to mutation, and from tissue to tissue. Large retrospective studies have shown that the percentage level of mutated mtDNA in clinically relevant tissues does correlate with the severity of disease. ${ }^{38}{ }^{39}$

\section{Maternal inheritance and the genetic bottleneck}

Although it has been known for some time that mtDNA is transmitted from mother to offspring, ${ }^{40}$ the mechanisms are only just becoming clear. Sperm contain around 100 mtDNAs which enter the zygote on fertilisation before being actively degraded ${ }^{41}$ There has been a recent report of a pathogenic mtDNA microdeletion in a patient with a sporadic muscle specific mitochondrial disorder. ${ }^{42}$ The mutated mtDNA arose on a mitochondrial genome that was paternal in origin, bringing into question the traditional dogma of strict maternal inheritance. However, many families with mtDNA disease have been studied in detail over the last decade, and there are no other reports of paternal mtDNA transmission. Based upon the available evidence, paternal leakage is unlikely to be clinically significant.

One of the most remarkable features of mitochondrial disease caused by mtDNA defects is the clinical variability among siblings. This is thought to reflect the mitochondrial "genetic bottleneck". ${ }^{43}$ Our understanding of the transmission of mtDNA heteroplasmy has been greatly advanced by detailed studies of heteroplasmic mice generated by karyoplast transfer. ${ }^{44}$ These mice transmit heteroplasmic mtDNA polymorphisms (table 3 ). By measuring the variation in heteroplasmy between the offspring of a single female, and 


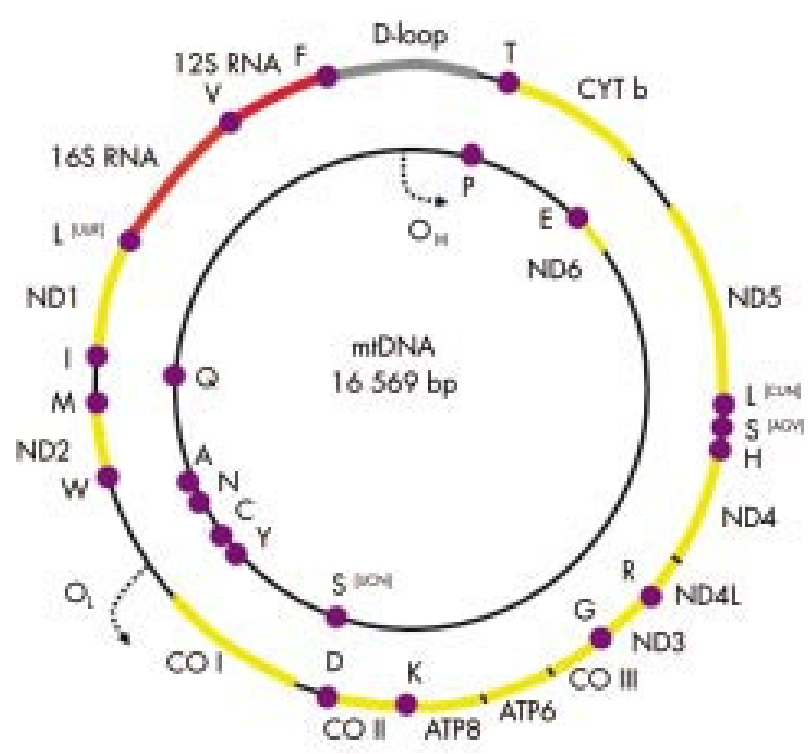

Figure 3 The human mitochondrial genome. The human mitochondrial genome (mtDNA) is a small $16569 \mathrm{~kb}$ molecule of double stranded DNA. mtDNA encodes for 13 essential components of the respiratory chain. ND1-ND6 and ND4L encode seven subunits of complex I (NADH-ubiquinone oxidoreductase). CYT b is the only mtDNA encoded complex III subunit (ubiquinol-cytochrome $c$ oxidase reductase). COX I to III encode for three of the complex IV (cytochrome $c$ oxidase, or COX) subunits, and the ATP 6 and ATP 8 genes encode for two subunits of complex V (ATP synthase). Two ribosomal RNA genes (12S and 16S rRNA), and 22 transfer RNA genes are interspaced between the protein encoding genes. These provide the necessary RNA components for intramitochondrial protein synthesis. D-loop, the $1.1 \mathrm{~kb}$ non-coding region which is involved in the regulation of transcription and replication of the molecule, and is the only region not directly involved in the synthesis of respiratory chain polypeptides; $\mathrm{O}_{H}$ and $\mathrm{O}_{L}$, the origins of heavy and light strand mtDNA replication.

comparing this to the variation between oocytes at different stages of development, it was shown that the transmitted percentage level of heteroplasmy is determined at an early stage during oogenesis in a heteroplasmic female developing in utero. ${ }^{44}$ It is likely that there is a restriction in the number of mitochondrial genomes during early oogenesis, creating a functional "genetic bottleneck". This creates a sampling effect, akin to taking a small handful of marbles from a bag containing a large number of well mixed black and white marbles while wearing a blindfold. Each independent sample will contain different proportions of the two types, corresponding to mutated and wild-type mtDNA in the offspring. Recent work suggests that the same random mechanism operates during the transmission of pathogenic mtDNA mutations in humans. ${ }^{56}{ }^{57}$ While this generates variability in the transmitted mutation load to the offspring, it occurs within a given confidence interval, explaining why retrospective family studies have shown a relation between the level of mutated mtDNA in the mother and the outcome of pregnancy. ${ }^{39} 58$

Although differences in the transmitted mutation load provide some explanation for the difference in severity between different family members, it does not explain why one sibling might present with neurological disease while another might develop heart failure. Clearly additional factors must come in to play.

The percentage level of mutated mtDNA in individual tissues may also change during development and throughout adult life, potentially influencing the phenotype within an individual. Two mechanisms contribute to this process: relaxed replication and mitotic segregation.

\section{Relaxed replication}

Unlike nuclear DNA which replicates only once during each cell cycle, mtDNA is continuously recycled, even in nondividing tissues such as skeletal muscle and brain. ${ }^{59}{ }^{60} \mathrm{mtDNA}$ replication is therefore independent of the cell cycle (that is, it is relaxed). In a heteroplasmic cell, it is possible that mutated and wild-type mtDNA replicate at subtly different rateseither because one type was selected for destruction or replication by chance, or because of a subtle selective effect in favour of one particular type. In theory, this mechanism could lead to changes in the proportion of mutated mtDNA that have been described in patients with mtDNA disease, providing an explanation for the late onset and progression of some mtDNA disorders. ${ }^{61}$

\section{Mitotic (vegetative) segregation}

When a heteroplasmic cell divides, subtle differences in the proportion of mutated mtDNA may be passed on to the daughter cells, leading to changes in the level of mutated mtDNA within a dividing tissue ${ }^{60}{ }^{62}$ The unequal partitioning may be a purely random process, independent of any selection caused by an effect of the mutation on mitochondrial function. On the other hand, presumed shifts due to functional selection may explain why the level of some pathogenic mtDNA mutations decreases in blood during life (for example, $0.5 \%$ to $1 \%$ per annum for $\mathrm{A} 3243 \mathrm{G}^{63}$ ).

\section{mtDNA "background," nuclear genes, and the environment}

While there are a great many different heteroplasmic mtDNA mutations, in epidemiological terms most patients with a pathogenic mtDNA defect harbour only mutated mtDNA (that is, they are homoplasmic mutated). ${ }^{64}$ The most common example is LHON (Leber hereditary optic neuropathy). ${ }^{64}$ LHON is a mitochondrial genetic disorder that is primarily caused by mutations in mtDNA complex I (ND) genes and is characterised by subacute bilateral visual failure presenting in early adult life. ${ }^{65}$ LHON is intriguing because it is essentially an organ specific disease that principally affects the retinal ganglion cells and the optic nerve. ${ }^{66}$ LHON also has a markedly reduced penetrance with a clear sex bias, with only around $50 \%$ of men and around $10 \%$ of women developing visual failure. ${ }^{356768}$ Most patients with LHON are homoplasmic mutated for one of three mtDNA ND gene mutations (fig 4), ${ }^{69}$ so heteroplasmy cannot explain the varied disease penetrance, and certain unknown additional factors appear to be important.

Wild-type (normal) mtDNA can be subdivided into different genetic groups (haplogroups) based upon a characteristic pattern of polymorphism that occurs within the normal population. ${ }^{70}$ Two of the three principal LHON mtDNA mutations (T14484C in the ND6 gene and G11778A in the ND4 gene) are preferentially associated with haplogroup J, which is found in around 15\% of northern Europeans. ${ }^{71}$ The reason for this association is not known, but it seems likely that haplogroup $\mathrm{J}$ increases the penetrance of the T14484C and G11778A mutations. ${ }^{72}$ It therefore appears that the mitochondrial genetic background can influence disease expression, but this cannot explain the sex bias in LHON.

The segregation pattern of disease in some LHON families suggests that there may be a nuclear genetic modifier locus modulating the clinical expression of the LHON mtDNA mutations. A recessive visual loss susceptibility locus on the $\mathrm{X}$ chromosome would explain the sex bias in LHON, $^{73}$ but attempts to identify the locus have not been successful. ${ }^{74}$ Environmental factors may also play a part in LHON. There are many anecdotal reports of visual failure following alcohol intoxication, starvation, heavy smoking, and head trauma, ${ }^{68}$ but large studies have yielded conflicting results. ${ }^{75} 76$ 
Table 1 Genetic classification of human mitochondrial disorders

\begin{tabular}{|c|c|}
\hline Type of disorder & $\begin{array}{l}\text { Inheritance } \\
\text { pattern }\end{array}$ \\
\hline \multicolumn{2}{|l|}{ Mitochondrial genetic disorders* } \\
\hline \multicolumn{2}{|l|}{ Rearrangements (large scale partial deletions and duplications) } \\
\hline Chronic progressive external ophthalmoplegia (CPEO) & $\mathrm{s}$ \\
\hline Kearns-Sayre syndrome & S \\
\hline Diabetes and deafness & S \\
\hline Pearson marrow-pancreas syndrome & $\mathrm{S}$ \\
\hline Sporadic tubulopathy & $\mathrm{s}$ \\
\hline \multicolumn{2}{|l|}{ Point mutations } \\
\hline \multicolumn{2}{|l|}{ Protein encoding genes } \\
\hline - LHON (G11778A, T14484C, G3460A) & M \\
\hline - NARP/Leigh syndrome (T8993G/C) & M \\
\hline \multicolumn{2}{|l|}{ tRNA genes } \\
\hline - MELAS (A3243G, T3271C, A3251G) & M \\
\hline - MERRF (A8344G, T8356C) & M \\
\hline - CPEO (A3243G, T4274C) & M \\
\hline - Myopathy (T14709C, A12320G) & M \\
\hline - Cardiomyopathy (A3243G, A4269G, A4300G) & M \\
\hline - Diabetes and deafness (A3243G, C12258A) & M \\
\hline - Encephalomyopathy (G1606A, T10010C) & M \\
\hline \multicolumn{2}{|l|}{ rRNA genes } \\
\hline - Non-syndromic sensorineural deafness (A7445G) & M \\
\hline - Aminoglycoside induced non-syndromic deafness (A1555G) & M \\
\hline \multicolumn{2}{|l|}{$\begin{array}{l}\text { Nuclear genetic disorders } \\
\text { Disorders of mtDNA maintenance }\end{array}$} \\
\hline \multicolumn{2}{|l|}{ Autosomal dominant progressive external ophthalmoplegia (with $2^{\circ}$ multiple mtDNA deletions) } \\
\hline - Mutations in adenine nucleotide translocator (ANTI) & $A D$ \\
\hline - Mutations in DNA polymerase $\gamma$ (POLG) & $A D$ or $A R$ \\
\hline - Mutations in Twinkle helicase (C10orf2) & $A D$ \\
\hline \multicolumn{2}{|l|}{ Mitochondrial neuro-gastrointestinal encephalomyopathy (with $2^{\circ}$ multiple mtDNA deletions) } \\
\hline - Mutations in thymidine phosphorylase (TP) & AR \\
\hline \multicolumn{2}{|l|}{ Myopathy with m+DNA depletion } \\
\hline - Mutations in thymidine kinase (TK2) & AR \\
\hline \multicolumn{2}{|l|}{ Encephalopathy with liver failure } \\
\hline - Mutations in deoxyguanosine kinase (DGK) & AR \\
\hline \multicolumn{2}{|l|}{$\begin{array}{l}\text { Primary disorders of the respiratory chain } \\
\text { Leigh syndrome }\end{array}$} \\
\hline - Complex I deficiency: mutations in complex I subunits (NDUFS2, 4, 7, 8, and NDUFV1) & AR \\
\hline • Complex II deficiency: mutations in complex II flavoprotein subunit (SDH) & AR \\
\hline \multicolumn{2}{|l|}{ Leukodystrophy and myoclonic epilepsy } \\
\hline - Complex I deficiency: mutations in complex I subunit (NDUFVI) & AR \\
\hline \multicolumn{2}{|l|}{ Cardioencephalomyopathy } \\
\hline - Complex I deficiency: mutations in complex I subunit (NDUFS2) & AR \\
\hline \multicolumn{2}{|l|}{ Optic atrophy and ataxia } \\
\hline - Complex II deficiency: mutations in complex II flavoprotein subunit (SDH) & $A D$ \\
\hline \multicolumn{2}{|l|}{ Disorders of mitochondrial protein import } \\
\hline \multicolumn{2}{|l|}{ Dystonia-deafness } \\
\hline \multirow{2}{*}{\multicolumn{2}{|c|}{$\begin{array}{l}\text { Disorders of assembly of the respiratory chain } \\
\text { Leigh syndrome }\end{array}$}} \\
\hline & \\
\hline - Complex IV deficiency: mutations in COX assembly protein (SURFI) & AR \\
\hline \multirow{2}{*}{\multicolumn{2}{|c|}{$\begin{array}{l}\text { Cardioencephalomyopathy } \\
\text { Cufations in CUX assembly protein (COXIO) }\end{array}$}} \\
\hline & \\
\hline - Complex IV deficiency: mutations in COX assembly protein (SCO2) & AR \\
\hline \multicolumn{2}{|l|}{ Hepatic failure and encephalopathy } \\
\hline - Complex IV deficiency: mutations in COX assembly protein (SCOI) & AR \\
\hline - Complex IV deficiency: mutations in protein affecting COX mRNA stability (LRPPRC) & AR \\
\hline Tubulopathy, encephalopathy, and liver failure & \\
\hline - Complex III deficiency: mutations in complex III assembly (BCSIL) & AR \\
\hline
\end{tabular}

In many ways LHON is best considered as a complex trait, where the disease phenotype arises through multiple genetic factors (both mitochondrial and nuclear) interacting with the environment. A similar mechanism might explain the variable penetrance of other homoplasmic mtDNA mutations that cause organ specific disease, such as the Al555G mtDNA mutation in the $12 \mathrm{~S}$ rRNA gene that causes maternally inherited susceptibility to aminoglycoside induced deafness, and possibly the A4300G mtDNA mutation in tRNA ${ }^{\text {Ile }}$ that causes maternally inherited cardiomyopathy (see table 1). Similar nuclear-mitochondrial interactions are also likely to contribute to the varied phenotype seen in other mitochondrial disorders, be they caused by primary nDNA defects or primary mtDNA defects.

\section{Nuclear genes and mtDNA heteroplasmy}

After heteroplasmic mice were generated from laboratory strains with two different mtDNA genotypes in the mid-90s (see table 3), ${ }^{44}$ it became clear that a particular mitochondrial 
Table 2 Clinical syndromes associated with mitochondrial disease

\begin{tabular}{|c|c|c|}
\hline Syndrome & Primary features & Additional features \\
\hline $\begin{array}{l}\text { Chronic progressive external ophthalmoplegia } \\
\text { (CPEO) }\end{array}$ & External ophthalmoplegia and bilateral ptosis & Mild proximal myopathy \\
\hline $\begin{array}{l}\text { Infantile myopathy and lactic acidosis (fatal } \\
\text { and non-fatal forms) }\end{array}$ & $\begin{array}{l}\text { Hypotonia in the first year of life; feeding and } \\
\text { respiratory difficulties }\end{array}$ & $\begin{array}{l}\text { Fatal form may be associated with a cardiomyopathy } \\
\text { and/or the Toni-Fanconi-Debre syndrome }\end{array}$ \\
\hline Kearns-Sayre syndrome (KSS) & $\begin{array}{l}\text { PEO onset before age } 20 \text { with pigmentary } \\
\text { retinopathy, plus one of the following: CSF } \\
\text { protein }>1 \mathrm{~g} / \mathrm{l} \text {, cerebellar ataxia, heart block }\end{array}$ & $\begin{array}{l}\text { Bilateral deafness; myopathy; dysphagia; diabetes } \\
\text { mellitus and hypoparathyroidism; dementia }\end{array}$ \\
\hline Leber hereditary optic neuropathy (LHON) & $\begin{array}{l}\text { Subacute painless bilateral visual failure; } \\
\text { male:female approx } 4: 1 \text {; median age of onset } 24 \\
\text { years }\end{array}$ & Dystonia; cardiac pre-excitation syndromes \\
\hline Leigh syndrome (LS) & $\begin{array}{l}\text { Subacute relapsing encephalopathy with } \\
\text { cerebellar and brain stem signs presenting during } \\
\text { infancy }\end{array}$ & Basal ganglia lucencies \\
\hline $\begin{array}{l}\text { Mitochondrial encephalomyopathy with lactic } \\
\text { acidosis and stroke-like episodes (MELAS) }\end{array}$ & $\begin{array}{l}\text { Stroke-like episodes before age } 40 \text { years; seizures } \\
\text { and/or dementia; ragged-red fibres and/or lactic } \\
\text { acidosis }\end{array}$ & $\begin{array}{l}\text { Diabetes mellitus; cardiomyopathy (hypertrophic } \\
\text { leading to dilated); bilateral deafness; pigmentary } \\
\text { retinopathy; cerebellar ataxia }\end{array}$ \\
\hline $\begin{array}{l}\text { Myoclonic epilepsy with ragged-red fibers } \\
\text { (MERRF) }\end{array}$ & Myoclonus; seizures; cerebellar ataxia; myopathy & $\begin{array}{l}\text { Dementia, optic atrophy; bilateral deafness; peripheral } \\
\text { neuropathy; spasticity; multiple lipomata }\end{array}$ \\
\hline $\begin{array}{l}\text { Neurogenic weakness with ataxia and retinitis } \\
\text { pigmentosa (NARP) }\end{array}$ & $\begin{array}{l}\text { Late childhood or adult onset peripheral } \\
\text { neuropathy with associated ataxia and } \\
\text { pigmentary retinopathy }\end{array}$ & $\begin{array}{l}\text { Basal ganglia lucencies; abnormal electroretinogram; } \\
\text { sensorimotor neuropathy }\end{array}$ \\
\hline Pearson syndome & $\begin{array}{l}\text { Sideroblastic anaemia of childhood; } \\
\text { pancytopenia; exocrine pancreatic failure }\end{array}$ & Renal tubular defects \\
\hline
\end{tabular}

PEO, progressive external ophthalmoplegia.

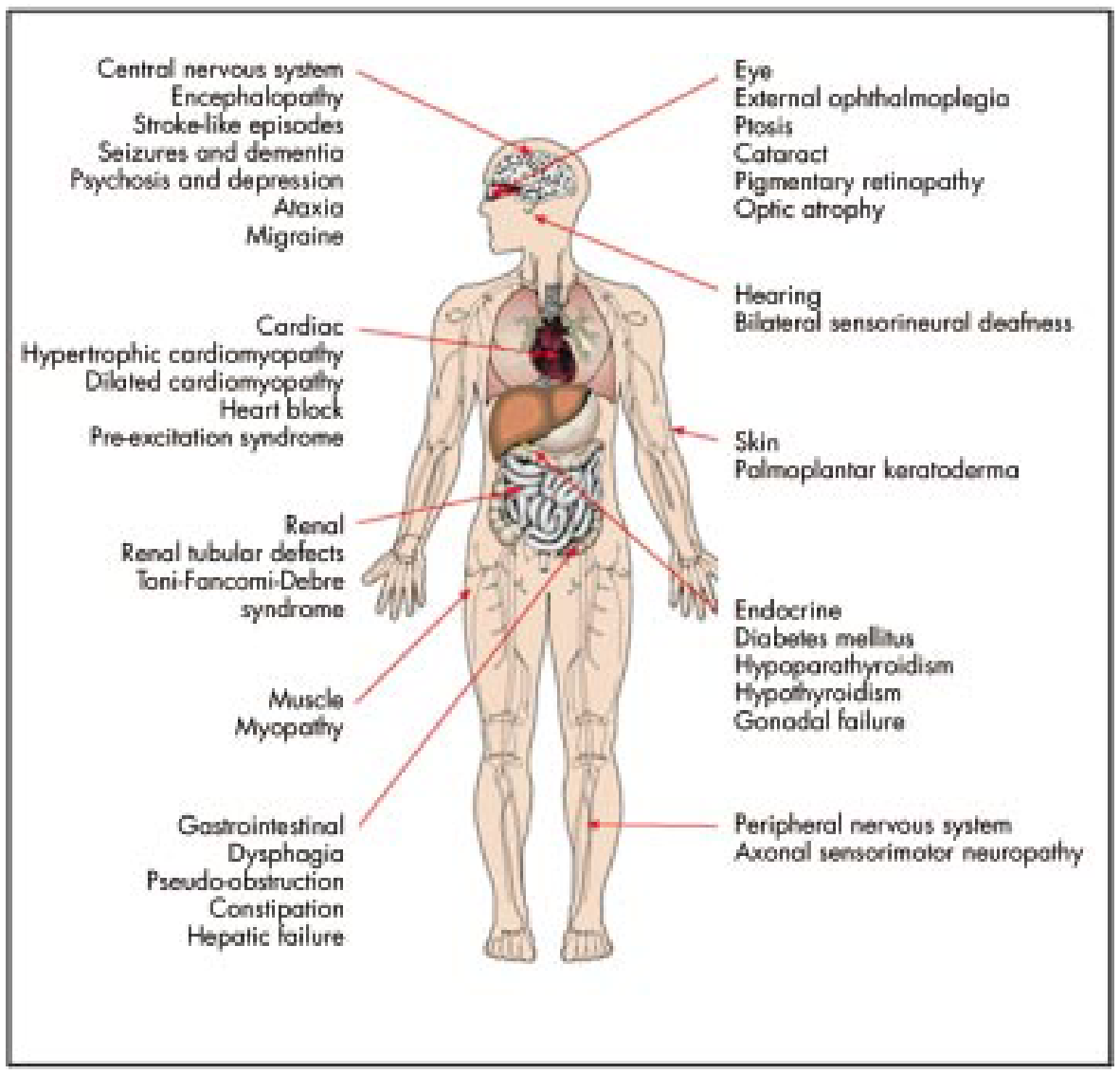

Figure 4 Clinical features of mitochondrial disease. Mitochondrial disease may present with single organ involvement (sensorineural deafness, diabetes, visual failure, myopathy, or cardiomyopathy), or multisystem involvement. It may be possible to recognise a specific clinical syndrome (table 2), but often patients do not fit neatly into one particular category. The combination of neurological disease and extraneurological involvement should raise the suspicion of a mitochondrial disorder.

genome was favoured in some tissues, and the other mitochondrial genome was favoured in others. ${ }^{77}$ Detailed experiments showed that this selective effect was not a result of detectable differences in respiratory chain activity or rates of mtDNA replication, and that the selection appeared to be controlled at the level of the mtDNA molecule itself. ${ }^{78}$ Recent work has identified three specific nuclear genetic loci that influence this process. ${ }^{79}$ This has important implications for our understanding of mtDNA diseases because the equivalent genes in humans might influence the level of heteroplasmy in different tissues and organs, and therefore modulate the clinical phenotype. 
Table 3 Animal models of mitochondrial disease (adapted from Larsson and Rustin ${ }^{47}$ )

\begin{tabular}{|c|c|c|c|c|}
\hline Type & Mouse model & Gene (reference) & Biochemical abnormality & Phenotype \\
\hline \multirow[t]{8}{*}{$\begin{array}{l}\text { Nuclear gene } \\
\text { knockouts }\end{array}$} & Adenosine nucleotide translocase & ANTI (48) & $\begin{array}{l}\text { Defect of coupled } \\
\text { respiration }\end{array}$ & Myopathy and cardiomyopathy \\
\hline & $\begin{array}{l}\text { Mitochondrial superoxide } \\
\text { dismutase }\end{array}$ & SOD2 (49) & $\begin{array}{l}\text { Mitochondrial superoxide } \\
\text { deficiency }\end{array}$ & Myopathy and cardiomyopathy \\
\hline & $\begin{array}{l}\text { Mitochondrial transcription factor } \\
\text { A }\end{array}$ & & & \\
\hline & Germ line & TFAM, germ line (25) & Respiratory chain defect & $\begin{array}{l}\text { Embryonic lethal. Abnormal } \\
\text { development with absence of heart } \\
\text { and optic disc }\end{array}$ \\
\hline & Heart specific & TFAM, tissue specific (50) & Respiratory chain defect & $\begin{array}{l}\text { Dilated cardiomyopathy and cardiac } \\
\text { conduction block }\end{array}$ \\
\hline & Pancreatic $\beta$ cell specific & TFAM, tissue specific (51) & Respiratory chain defect & Diabetes \\
\hline & COX assembly protein SURF-1 & SURF1 (52) & Respiratory chain defect & Embryonic lethality \\
\hline & Thymidine phosphorylase & TP (53) & $\begin{array}{l}\text { Reduction in liver TP } \\
\text { activity }\end{array}$ & None \\
\hline \multirow[t]{3}{*}{ Mitochondrial DNA } & BALB/NZB heteroplasmic & NZB/BALB mtDNA (44) & None & $\begin{array}{l}\text { Random drift during transmission. } \\
\text { Tissue specific selection of different } \\
\text { genotypes }\end{array}$ \\
\hline & Chloramphenicol resistance & $\begin{array}{l}\text { CAP-R T2443C mtDNA } \\
\text { (54) }\end{array}$ & None & $\begin{array}{l}\text { Myopathy, cardiomyopathy, perinatal } \\
\text { death }\end{array}$ \\
\hline & $\triangle m+D N A$ & $\begin{array}{l}4.7 \mathrm{~kb} m+D N A \text { deletion } \\
(46)\end{array}$ & & \\
\hline Spontaneous mutants & $\begin{array}{l}\text { Defect of nuclear-mitochondrial } \\
\text { communication }\end{array}$ & Not known (55) & None & Deafness \\
\hline
\end{tabular}

\section{Outlook}

The last five years have seen major advances in our understanding of mitochondrial genetics and how mtDNA mutations cause disease. Clinical expression is influenced by heteroplasmy, mtDNA background, nuclear genes, and their interaction with the environment. Evolutionary studies are casting light on this complex relation. For example, in the char (a fish), different environments, and particularly the water temperature, have selected in favour of a particular mitochondrial genotype. ${ }^{80}$ Recent work on humans suggests that the same phenomenon may have occurred during population migrations throughout the world. ${ }^{81}$ Understanding these processes is of fundamental importance for the clinical management of patients-from genetic counselling to developing new treatments.

\section{CONFIRMING SUSPECTED MITOCHONDRIAL DISEASE}

Our understanding of mitochondrial biochemistry and genetics has important implications for the investigation of suspected mitochondrial disease. In patients with a clearly defined clinical syndrome it may be possible to confirm the diagnosis with a simple molecular genetic test carried out on DNA extracted from blood. A good example of this is Leber hereditary optic neuropathy, where over $97 \%$ of cases are caused by one three defined mtDNA point mutations that are usually homoplasmic in blood. ${ }^{82}$ A similar approach may also be possible for nuclear genetic mitochondrial disorders (see table 1 , although most of these genetic tests are still within the realms of research and are not part of a routine diagnostic service). Investigating the remaining patients is more complex, partly because many disorders may mimic mitochondrial disease and also because there is no one single test that will prove or disprove whether a patient has a mitochondrial disorder. Many different genetic defects in both mitochondrial and nuclear DNA can cause similar neurological disorders, so rather than carry out a series of random genetic tests, it is better to approach the problem systematically to identify and characterise the underlying metabolic defect.

Heteroplasmy is the main problem when investigating mtDNA disorders. Pathogenic mtDNA mutations may not be detectable in blood using conventional techniques, and, almost counterintuitively, direct sequencing of mtDNA is the least robust technique of all. This means that a negative blood test result does not exclude a particular genetic diagnosis (for example, see Chinnery et al, $1997^{83}$ ). If mitochondrial disease is suspected and the blood DNA tests are negative, the patient should have a muscle biopsy (usually the first choice in adults) or a skin biopsy (usually the first choice in children). Urine sediment, and to a lesser degree hair follicles, are excellent sources for non-invasive mtDNA testing. ${ }^{84}$

Fresh muscle can be analysed histologically and histochemically for evidence of mitochondrial disease. Characteristic features include ragged red fibres which can be seen with the Gomori-trichrome stain ${ }^{85}$ or with succinate dehydrogenase histochemistry ${ }^{86}$ The ragged red appearance is caused by the subsarcolemmal accumulation of mitochondria and is thought to be a response to metabolic stress within a diseased muscle cell. ${ }^{87}$ There may also be a reduction in cytochrome $c$ oxidase activity (COX, complex IV) either within some of the fibres (a mosaic defect, suggestive of a mtDNA disorder ${ }^{88}$ but see Sasarman et al, 2002 ${ }^{89}$ ) or affecting all the fibres within the entire biopsy (suggesting a nuclear genetic defect).

Specialist centres carry out measurements of the individual respiratory chain complexes, which may also provide a clue to the underlying genetic defect. These can be done on fresh muscle or cultured fibroblasts grown from a skin biopsy. If a single complex is deficient, this points to a genetic defect in the relevant coding region of mtDNA or nuclear DNA, or a gene involved in the assembly of that particular complex. If there are multiple complex defects, that suggests a generalised defect of protein synthesis, and an underlying mtDNA defect involving a tRNA gene (including deletions that remove tRNA genes), or perhaps a nuclear gene defect with secondary effects on mtDNA. It is worth remembering that mitochondrial biochemical tests carried out on muscle and fibroblasts in the laboratory measure mitochondrial function under optimal conditions. It is therefore possible that there is a functional defect of mitochondrial metabolism that is not detectable in the laboratory (mutations in the ATPase 6 gene causing NARP (neurogenic weakness with ataxia and retinitis pigmentosa) are a good example of this pitfall). Evidence of impaired mitochondrial function may only be apparent on 
Table 4 Mitochondria on the world wide web

\begin{tabular}{|c|c|c|}
\hline Information & Name & URL \\
\hline \multirow[t]{3}{*}{ Information for patients } & $\begin{array}{l}\text { United Mitochondrial Diseases } \\
\text { Foundation (USA) }\end{array}$ & www.umdf.org \\
\hline & Mitolinks (UK) & $\begin{array}{l}\text { http://www.communigate.co.uk/ne/ } \\
\text { mitolinks/index.phtml }\end{array}$ \\
\hline & $\begin{array}{l}\text { Leber hereditary optic neuropathy } \\
\text { trust (UK) }\end{array}$ & www.leberstrust.btinternet.co.uk \\
\hline $\begin{array}{l}\text { Clinical and molecular } \\
\text { information for clinicians } \\
\text { and scientists }\end{array}$ & $\begin{array}{l}\text { On-line Mendelian Inheritance in } \\
\text { Man }\end{array}$ & www.ncbi.nlm.nih.gov \\
\hline $\begin{array}{l}\text { Clinical and genetic } \\
\text { information for clinicians } \\
\text { and patients }\end{array}$ & $\begin{array}{l}\text { Mitomap } \\
\text { Geneclinics }\end{array}$ & $\begin{array}{l}\text { www.mitomap.org } \\
\text { www.geneclinics.org }\end{array}$ \\
\hline Molecular data for scientists & Uppsala & $\begin{array}{l}\text { hitp://www.genpat.uu.se/mtDB/ } \\
\text { index.html }\end{array}$ \\
\hline \multirow{2}{*}{$\begin{array}{l}\text { Biochemical and molecular } \\
\text { data for scientists }\end{array}$} & Mitop & mips.gsf.de/proj/medgen/mitop \\
\hline & Mitodat & http://www-lecb.ncifcrf.gov/mitoDat/ \\
\hline
\end{tabular}

clinical testing using techniques such as exercise testing with lactate measurements, ${ }^{90}$ magnetic resonance spectroscopy, ${ }^{91}$ or infrared spectroscopy..$^{22}$

A structured approach to investigation allows targeted genetic analysis, which often means a Southern blot of muscle mtDNA looking for a mtDNA rearrangement, a series of allele specific assays looking for common point mutations of mtDNA or nuclear DNA, and direct sequencing of the relevant genes. A significant proportion of adults have rare or unique mtDNA defects (that is, "private" mutations). These are identified by mtDNA sequencing which should also be carried out on DNA extracted from muscle (but with the caveat noted above).

\section{Proving a mtDNA mutation is pathogenic}

mtDNA is highly polymorphic, with any two individuals differing at up to 60 base pairs (see the mtDNA sequence databases in table 4). The variation is so great that it is not unusual to find unique base changes in control individuals. This presents a particular problem when investigating patients with suspected mtDNA disorders-when is the base change a neutral polymorphism and when is it pathogenic?

Five "canonical" criteria suggest that a novel base change is pathogenic ${ }^{29}$ :

- The mutation must not be a known polymorphism (as described on one of the established sequence data bases, see table 4).

- The base change must affect a site that has been conserved during evolution. If the site is conserved across species then it implies that it is functionally important, and a mutation at this site is likely to be deleterious. The mutation must also be in a region that is functionally important. This essentially means anywhere in the tRNA genes, certain regions of the rRNA genes, or causing an amino acid change in the protein encoding genes.

- Deleterious mutations are usually (but not exclusively) heteroplasmic. This implies that the mutation occurred recently and it has not had time to "fix" in the female line, or that there has been selection against fixation acting at the level of the organism.

- The mutation segregates with the disease clinically. For heteroplasmic mutations this means that severely affected individuals have a high percentage level of mutated mtDNA, and unaffected individuals have a lower percentage level of mutated mtDNA.

- The mutation segregates with the disease biochemically. This is usually achieved by single cell mtDNA analysis. ${ }^{93}$
Individual muscle fibres are microdissected from thick cross sections of muscle and the percentage level of mutated mtDNA is measured in histochemically normal and abnormal muscle fibres (either because they are ragged red or COX deficient). For a pathogenic mutation, the percentage level of mutated mtDNA will be higher in the pathologically abnormal fibres.

\section{MANAGING MITOCHONDRIAL DISEASE-THE FUTURE}

Making a specific genetic diagnosis is helpful in various ways. It allows a comparison of that individual with other patients described in published reports, providing some guide to prognosis and highlighting complications that may evolve over time (table 2). It also has implications for genetic counselling (table 1). ${ }^{94}$ Nuclear defects may be autosomal recessive, autosomal dominant, or sex linked. mtDNA defects may be sporadic or maternally transmitted. There are no statistically based robust counselling guidelines for mtDNA disease, ${ }^{95}$ but data collection is underway, and they should become available over the next five years. Retrospective studies suggest that measuring the percentage level of mutated mtDNA in the mother will provide some guidance. ${ }^{3958}$

At present the management of mitochondrial disease is largely supportive and aimed at identifying, preventing, and treating complications wherever possible. Pharmacological treatments have been used with varying degrees of success (recently reviewed by Chinnery \& Turnbull ${ }^{96}$ ). Limited clinical trials have been carried out, but no consistent clinical improvements have been demonstrated. A multicentre trial is currently under way for dichloracetate to reduce lactic acidosis in MELAS patients.

Our understanding of the basic biology of mitochondrial disease provides a basis for developing new treatments. Several strategies have been employed to try and correct the underlying genetic defect. The overall aim is to reduce the proportion of mutated mtDNA to subthreshold levels. This could be achieved by adding more wild-type mtDNA, or by removing mutated mtDNA.

\section{Adding wild-type mtDNA}

Despite initial promise, ${ }^{46}$ attempts to deliver synthetic wild-type mtDNA into cells have not been successful. A more attractive strategy is to move wild-type mitochondrial genomes from one compartment to another-an approach called "gene shifting". ${ }^{97-99}$ Healthy skeletal muscle contains small precursors called satellite cells. Satellite cells proliferate and fuse with the juxtapositionary mature skeletal fibres in 
response to stress and exercise. In some patients with mtDNA myopathy, the percentage level of mutated mtDNA in satellite cells is lower that the level in affected skeletal muscle. It is possible to induce satellite cell proliferation by injecting a toxin into muscle (such as bupivacaine ) $^{9798}$ or by exercising the muscle. ${ }^{99}$ Both techniques have been shown to deliver wild-type mtDNA from the satellite cell compartment into mature muscle fibres, to reduce the proportion of mutated mtDNA within affected tissues, and to correct the biochemical defect. Exercise also improves the strength and stamina of patients with mtDNA myopathy ${ }^{100}$ - but there are concerns that it may also increase the amount of mutated mtDNA in the muscle, leading to short term improvements that may be detrimental in the longer term. ${ }^{101}$

\section{Removing mutated mtDNA}

Two strategies have been employed to remove mutated mtDNA. Both are at the experimental stage, and both require considerable development before they can be used on patients. One approach has been to develop synthetic molecules that bind to mutated mtDNA molecules and prevent them from replicating, but allowing wild-type mtDNA replication to continue unimpeded. ${ }^{102}$ While this strategy works in vitro, and it appears that the "antigenomic" molecules can be delivered into mitochondria, ${ }^{103}$ so far it has not been possible to influence the level of heteroplasmy in living cells. An alternative approach is to use drugs that select against mutated mtDNA in dividing cells, allowing wild-type mtDNA levels to increase. ${ }^{104}$

All of these approaches have the same drawback-even if they are effective, how can the treatments be delivered to the nervous system and alter the mtDNA levels in non-dividing cells? For this reason perhaps the best strategy is to remove all mutated mtDNA at an early stage in development, by nuclear transfer. By removing the nucleus from an affected zygote with a mtDNA mutation and inserting it into a healthy enucleated donor with normal mtDNA, it should be possible to form healthy offspring that do not harbour the mtDNA defect, thereby preventing the disease in that individual, and also preventing further transmission of the disease. This approach is currently at an experimental stage, but provides some hope for the future.

\section{ANIMAL MODELS}

Various mouse models for mitochondrial disease have been developed over the last five years. It is hoped that these models will advance our understanding of the pathophysiology and will also be useful for developing new treatments (table 3). Most of the models were produced by nuclear gene manipulation, and some bear clinical or pathological resemblances to human mitochondrial diseases. Developing a good model for human mtDNA disorders is proving difficult because it is currently not possible to transfect mammalian mitochondria with exogenous DNA. To get around this problem, Inoue and colleagues fused synaptic nerve terminals (synaptosomes) from aged mice harbouring low levels of mtDNA deletions with cybrid cells. ${ }^{105}$ They screened the cybrid clones for detectable levels of mtDNA deletions and fused one with a mouse zygote that was implanted into a foster mother. The offspring contained a mixture of wild-type mtDNA and mtDNA with a $4.7 \mathrm{~kb}$ deletion. These mice share some clinical features with human mtDNA deletion disorders, but they were remarkable in two respects. First, the mice developed a nephropathy (a feature not typically found in KSS), and second, the female offspring also harboured deleted mtDNA (also not typical of KSS). Thus, like many other mouse models, there is not a complete correspondence between the human and the murine phenotype. To some extent this is inevitable-human mtDNA disorders are late onset diseases, and it is difficult to mimic the effects of aging in other shorter

\section{Box 1 Areas for future development}

- GENETIC COUNSELLING - There are currently no statistically-derived genetic counselling guidelines for mtDNA disease. A multi-national consortium is currently collecting data, and robust guidelines should become available in the next few years when a large cohort has been assembled.

- NUCLEAR-MITOCHONDRIAL INTERACTIONS - By studying relatively rare mitochondrial disorders we will increase our understanding of the way that mitochondria interact with cellular metabolism and particularly the cell nucleus. It is likely that this will have a broader relevance for other neurological diseases.

- ANIMAL MODELS - We currently do not have a good model for heteroplasmic mtDNA point mutation disorders (such as "MELAS" or "MERRF" - see table 2), but there is considerable effort worldwide to generate the model. Many of the unanswered questions about genotype and phenotype can be addressed when the model becomes available, and it may be used to test new treatments.

- NOVEL TREATMENTS - There are currently no treatments for mitochondrial disease, but various avenues show promise, and are likely to enter clinical practice within the next decade (see text).

- ENVIRONMENTAL/EXTERNAL FACTORS - Although it is generally accepted that exogenous factors influence mitochondrial function in humans, identifying them is proving difficult. Population based studies and the further investigation of animal models are likely to provide some insight. If these exogenous factors can be changed (by dietary or pharmacological manipulation), this approach may open up avenues for new treatments.

lived mammals. Attempts to generate mice transmitting mtDNA point mutations similar to those found in humans have not yet been forthcoming.

\section{CONCLUSIONS}

Mitochondria have an essential role in maintaining cellular homeostasis, and their many functions integrate closely with the cellular metabolic network. It is therefore naive to think of mitochondria in isolation, and although we recognise primary disorders of mitochondrial function, the cellular and clinical consequences will depend on many other genetic and environmental factors. Precisely how the jigsaw fits together will vary from person to person. This presents a unique challenge to neurologists wanting to identify, diagnose, and manage patients and families with mitochondrial disease. In this respect, areas for future development are highlighted in box 1 .

These are not rare disorders. Recent epidemiological studies have shown that as a group primary mitochondrial disorders affect at least one in 8000 of the general population, ${ }^{95}$ and that number is likely to increase as the genotypic and phenotypic spectrum expands. It is also becoming clear that mitochondrial dysfunction occurs in many common sporadic neurological disorders, and there may be common mitochondrial mechanisms associated with certain neurological phenotypes (a good example being the various forms of hereditary spastic paraplegia). Our grasp of primary mitochondrial disorders will therefore have a much broader relevance, helping us to understand many other diseases and hopefully leading to novel generic treatments for neurological diseases.

\section{ACKNOWLEDGEMENTS}

PFC is funded by the Wellcome Trust and Ataxia (UK). EAS is funded by the US National Institutes of Health, the Muscular Dystrophy Association, and the National Organisation for Rare Diseases. We are grateful to Dr Zofia Chrzanowska-Lightowlers for fig 2. 


\section{GLOSSARY}

ANT: Adenine nucleotide translocator. A transporter protein that exchanges ADP for ATP across the mitochondrial inner membrane. There are various tissue specific isoforms of ANT. Mutations in the nuclear gene ANTl cause autosomal dominant chronic progressive external ophthalmoplegia with secondary mtDNA deletion formation (see table 1). There is a mouse knockout model for the cardiac isoform of ANT (see table 3).

Apoptosis: Programmed cell death. A critical process essential for normal development and cell turnover. The release of cytochrome $c$ from the inner mitochondrial membrane is one mechanism that can trigger apoptosis. This is discussed in detail in other articles in this series.

ATP: Adenosine triphosphate. A high energy phosphate molecule produced by the respiratory chain from ADP. ATP is required for all active cellular processes.

Cybrid cell: Cultured cell generated by fusing the cytoplasm of one cell (cytoplast) with that of another. This technique can be used to generate cell lines with different levels of heteroplasmy on a specific nuclear genetic background.

Cytoplasmic transfer: Technique used to generate heteroplasmic mice. Cytoplasm containing mitochondria from one inbred mouse strain (for example, NZB) are transferred and fused with an early embryonic cell from another cell inbred mouse strain (for example, BALB).

Genetic bottleneck (mitochondrial): A restriction in the number of mitochondrial genomes during early development of the female germ line causes a "sampling effect" which results in great variation in the level of heteroplasmy among the offspring of a heteroplasmic mother.

Haplogroup (mtDNA): mtDNA is highly polymorphic within the general population. There are certain groups of polymorphisms that reflect the maternal ancestry of a particular individual. These large groups are called haplogroups, and they contain individual haplotypes.

Haplotype (mtDNA): A specific mitochondrial genotype defined by a characteristic collection of mtDNA polymorphisms

Heteroplasmy: Mammalian cells contain many copies of mtDNA. Patients with mtDNA disease often harbour a mixture of mutated and wild-type mtDNA-a situation known as heteroplasmy. The proportion of mutated mtDNA can vary between zero and $100 \%$.

Homoplasmy: Mammalian cells contain many copies of mtDNA. Usually all of these copies are identical—a situation known as homoplasmy.

Knockout: Type of mouse model where a specific nuclear gene is removed.

Mitotic (vegetative) segregation: When a heteroplasmic cell divides, the daughter cells may receive different amounts of mutated mtDNA by chance.

mtDNA: Mitochondrial DNA. The 16569 base pair circular mitochondrial genome. Each cell contains thousands of copies.

Oxidative phosphorylation (OXPHOS): Electrochemical process carried out by the respiratory chain. Electrons received from reduced cofactors are passed between the different respiratory chain complexes; protons are pumped from the mitochondrial matrix into the inter-membrane space generating the mitochondrial membrane potential. The influx of protons through complex V is used to generate ATP from ADP and inorganic phosphate.

POLG: Polymerase $\gamma$-the only mitochondrial DNA polymerase. Mutations in the nuclear gene POLGl are a common cause of autosomal dominant and recessive chronic progressive external ophthalmoplegia with secondary mtDNA deletions (see table 1).

Polymorphism: A phenotypically neutral natural variation in DNA code at a particular site. In strict terms a particular sequence change must be present in $1 \%$ of the population to be a polymorphism, but the term is often used to describe any phenotypically neutral sequence variant.

Relaxed replication: Unlike nuclear DNA which is only copied during cell division, mtDNA is continuously recycled within the cell (while the overall amount is maintained at roughly constant levels).

Respiratory chain: A group of four enzyme complexes (I-IV) situated on the inner mitochondrial membrane. Together with ATP synthase (complex V), the respiratory chain is the final common pathway for aerobic energy metabolism and the production of ATP

Satellite cell: Muscle cell precursor situated adjacent to the mature muscle fibre. Satellite cells proliferate in response to muscle stress and fuse with the mature muscle fibre.

Threshold effect: Most mtDNA mutations only cause a biochemical defect of the respiratory chain when the proportion exceeds a critical threshold level. This threshold varies from tissue to tissue, and from mutation to mutation.

Wild-type: Normal DNA found in the outbred population

\section{Authors' affiliations}

P F Chinnery, Department of Neurology, The University of Newcastle upon Tyne, Newcastle upon Tyne, UK

E A Schon, Departments of Neurology and of Genetics and

Development, Columbia University, New York, USA

\section{REFERENCES}

1 Luft R, Ikkos D, Palmieri G, et al. A case of severe hypermetabolism of nonthyroid origin with a defect in the maintenance of mitochondrial respiratory control: a correlated clinical, biochemical and morphological study. J Clin Invest 1962;41:1776-804.

2 Shy GM, Gonatas NK, Perez M. Two childhood myopathies with abnormal mitochondria. I. Megaconial myopathy. II. Pleioconial myopathy. Brain 1966;89:133-58.

3 Rowland LP, Hays AP, Di Mauro S, et al. Diverse clinical disorders associated with abnormalities of mitochondria. In: Scarlato G, Cerri C, eds. Mitochondrial pathology in muscle diseases. Padova: Piccin, 1983:141-58.

4 Petty RK, Harding AE, Morgan-Hughes JA. The clinical features of mitochondrial myopathy. Brain 1986;109:915-38.

5 Nass S, Nass MMK. Intramitochondrial fibres with DNA characteristics. J Cell Biol 1963;19:593-629.

6 Anderson S, Bankier AT, Barrell BG, et al. Sequence and organization of the human mitochondrial genome. Nature 1981;290:457-65.

7 Wallace DC, Singh G, Lott MT, et al. Mitochondrial DNA mutation associated with Leber's hereditary optic neuropathy. Science 1988;242:1427-30

8 Holt I, Harding AE, Morgan-Hughes JA. Deletion of muscle mitochondrial DNA in patients with mitochondrial myopathies. Nature 1988:331:717-19.

9 Servidei S. Mitochondrial encephalomyopathies: gene mutation. Neuromuscul Disord 2003;13:109-14

10 Schon EA, Bonilla E, DiMauro S. Mitochondrial DNA mutations and pathogenesis. J Bioenerget Biomemb 1997;29:131-49.

11 Wallace DC. Mitochondrial diseases in mouse and man. Science 1999;283: 1482-8.

12 DiMauro S. Mitochondrial encephalomyopathies: back to Mendelian genetics. Ann Neurol 1999;45:693-4.

13 Shoubridge EA. Nuclear genetic defects of oxidative phosphorylation. Hum Mol Genet 2001;10:2277-84.

14 Alexander C, Votruba M, Pesch UE, et al. OPA 1, encoding a dynamin-related GTPase, is mutated in autosomal dominant optic atrophy linked to chromosome 3q28. Nat Genet 2000;26:211-15.

15 Rotig A, de Lonlay P, Chretien D, et al. Aconitase and mitochondrial iron-sulphur protein deficiency in Friedreich ataxia. Nat Genet 1997; 17:215-17.

16 Casari G, De Fusco M, Ciarmatori S, et al. Spastic paraplegia and OXPHOS impairment caused by mutations in paraplegin, a nuclear-encoded mitochondrial metalloprotease. Cell 1998:93:973-83.

17 Lutsenko S, Cooper M. Localization of the Wilson's disease protein product to mitochondria. Proc Natl Acad Sci USA 1998;95:6004-9

18 Leonard JV, Schapira AVH. Mitochondrial respiratory chain disorders II: neurodegenerative disorders and nuclear gene defects. Lancet 2000:355:389-94.

19 Van Goethem G, Dermaut B, Lofgren A, et al. Mutation of POLG is associated with progressive external ophthalmoplegia characterized by mtDNA deletions. Nat Genet 2001;28:211-12.

20 Nishino I, Spinazzola A, Hirano M. Thymidine phosphorylase gene mutations in MNGIE, a human mitochondrial disorder. Science 1999;283:689-92. 
21 Saada A, Shaag A, Mandel $H$, et al. Mutant mitochondrial thymidine kinase in mitochondrial DNA depletion myopathy. Nat Genet 2001;29:342-4.

22 Mandel H, Szargel R, Labay V, et al. The deoyguanosine kinase gene is mutated in individuals with depleted hepatocerebral mitochondrial DNA. Nat Genet 2001;29:337-41.

23 Kaukonen J, Juselius JK, Tiranti V, et al. Role of adenine nucleotide translocator 1 in mtDNA maintenance. Science 2000;289:782-5.

24 Spelbrink JN, Li FY, Tiranti V, et al. Human mitochondrial DNA deletions associated with mutations in the gene encoding Twinkle, a phage T7 gene 4-like protein localised in mitochondria. Nat Genet $2001 ; 28: 223-31$.

25 Larsson NG, Wang J, Wilhelmsson $\mathrm{H}$, et al. Mitochondrial transcription factor $A$ is necessary for m+DNA maintenance and embryogenesis in mice. Nat Genet 1998;18:231-6.

26 Falkenberg M, Gaspari M, Rantanen A, et al. Mitochondrial transcription factors $B 1$ and $B 2$ activate transcription of human m+DNA. Nat Genet 2002:31:289-94

27 Chinnery PF, Howell N, Andrews RA, et al. Clinical mitochondrial genetics. J Med Genet 1999;36:425-36.

28 Leonard JV, Schapira AH. Mitochondrial respiratory chain disorders I: mitochondrial DNA defects. Lancet 2000;355:299-304.

29 DiMauro S, Schon EA. Mitochondrial DNA mutations in human disease. Am J Med Genet 2001;106:18-26.

30 Holt IJ, Harding AE, Petty RK, et al. A new mitochondrial disease associated with mitochondrial DNA heteroplasmy. Am J Hum Genet 1990;46:428-33.

31 Tiranti V, Hoertnagel K, Carrozzo R, et al. Mutations of SURF-1 in Leigh disease associated with cytochrome c oxidase deficiency. Am J Hum Genet 1998;63:1609-21.

32 Ciafaloni E, Ricci E, Shanske S, et al. MELAS: clinical features, biochemistry, and molecular genetics. Ann Neurol 1992;31:391-8.

33 Moraes CT, Ciacci F, Silvestri G, et al. Atypical clinical presentations associated with the MELAS mutation at position 3243 of human mitochondrial DNA. Neuromuscul Disord 1993;3:43-50.

34 Reardon W, Ross RI, Sweeney MG, et al. Diabetes mellitus associated with a pathogenic point mutation in mitochondrial DNA. Lancet 1992;340:1376-9.

35 Nikoskelainen EK. Clinical picture of LHON. Clin Neurosci 1994;2:115-20.

36 Prezant TR, Agapian JV, Bohlman MC, et al. Mitochondrial ribosomal RNA mutations associated with both antibiotic-induced and non-syndromic deafness. Nat Genet 1993;4:289-94.

37 King MP, Attardi G. Injection of mitochondria into human cells leads to a rapid replacement of the endogenous mitochondrial DNA. Cell 1988:52:811-19.

38 Chinnery PF, Howell N, Lightowlers RN, et al. Molecular pathology of MELAS and MERRF. The relationship between mutation load and clinical phenotypes. Brain 1997;120:1713-21

39 White SL, Collins VA, Woolfe R, et al. Genetic counseling and prenatal diagnosis for the mitochondrial DNA mutations at nucleotide 8993. Am J Hum Genet 1999:65:474-82.

40 Giles RE, Blanc $\mathrm{H}$, Cann HM, et al. Maternal inheritance of human mitochondrial DNA. Proc Natl Acad Sci USA 1980;77:6715-19.

41 Sutovsky P, Moreno RD, Ramalho-Santos J, et al. Ubiquitin tag for sperm mitochondria. Nature 1999;403:371-2.

42 Schwartz $M$, Vissing J. Paternal inheritance of mitochondrial DNA. N Engl J Med 2002;347:576-80.

43 Poulton J, Macaulay V, Marchington DR. Mitochondrial genetics '98: Is the bottleneck cracked? Am J Hum Genet 1998;62:752-7.

44 Jenuth J, Peterson AC, Fu K, et al. Random genetic drift in the female germ line explains the rapid segregation of mammalian mitochondrial DNA. Nat Genet 1996;14:146-51.

45 Meirelles F, Smith LC. Mitochondrial genotype segregation in a mouse heteroplasmic lineage produced by embryonic karyoplast transplantation. Genetics 1997;145:445-51.

46 Seibel P, Trappe J, Villani G, et al. Transfection of mitochondria: strategy towards a gene therapy of mitochondrial DNA diseases. Nucleic Acids Res 1995;23:10-17.

47 Larsson NG, Rustin P. Animal models for respiratory chain disease. Trends Mol Med $2001 ; 7: 578-81$

48 Graham BH, Waymire KG, Cottrell B, et al. A mouse model for mitochondrial myopathy and cardiomyopathy resulting from a deficiency in the heart/muscle isoform of the adenine nucleotide translocator. Nat Genet 1997:16:226-34.

49 Li Y, Huang TT, Carlson EJ, et al. Dilated cardiomyopathy and neonatal lethality in mutant mice lacking manganese superoxide dismutase. Nat Genet 1995; 11:376-81.

50 Wang J, Wilhelmsson H, Graff C, et al. Dilated cardiomyopathy and atrioventricular conduction blocks induced by heart-specific inactivation of mitochondrial DNA expression. Nat Genet 1999;21:133-7.

51 Silva JP, Kohler M, Graff C, et al. Impaired insulin secretion and beta-cell loss in tissue-specific knockout mice with mitochondrial diabetes. Nat Genet 2000;26:336-40.

52 Agostino A, Invernizzi F, Tiveron C, et al. Constitutive knockout of Surfl is associated with high embryonic lethality, mitochondrial disease and cytochrome c oxidase deficiency in mice. Hum Mol Genet 2003; 12:399-413

53 Haraguchi $M$, Tsujimoto $H$, Fukushima $M$, et al. Targeted deletion of both thymidine phosphorylase and uridine phosphorylase and consequent disorders in mice. Mol Cell Biol 2002;22:5212-21.

54 Sligh JE, Levy SE, Waymire KG, et al. Maternal germ-line transmission of mutant mtDNAs from embryonic stem cell-derived chimeric mice. Proc Natl Acad Sci USA 2000;97:14461-6.
55 Johnson KR, Zheng QY, Bykhovskaya Y, et al. A nuclear-mitochondrial DNA interaction affecting hearing impairment in mice. Nat Genet 2001;27:191-4

56 Chinnery PF, Thorburn DR, Samuels DC, et al. The inheritance of mitochondrial DNA heteroplasmy: random drift, selection or both? Trends Genet 2000;16:500-5.

57 Brown DT, Samuels DC, Michael EM, et al. Random genetic drift determines the level of mutant mitochondrial DNA in human primary oocytes. Am J Hum Genet 2001;68:553-36

58 Chinnery PF, Howell N, Lightowlers RN, et al. MELAS and MERRF: the relationship between maternal mutation load and the frequency of clinically affected offspring. Brain 1998;121:1889-94.

59 Bogenhagen D, Clayton DA. Mouse L cell mitochondrial DNA molecules are selected randomly for replication throughout the cell cycle. Cell 1977;11:719-27.

60 Birky CW. The inheritance of genes in mitochondria and chloroplasts: laws, mechanisms, and models. Annu Rev Genet 2001:35:125-48.

61 Chinnery PF, Samuels DC. Relaxed replication of mtDNA: a model with implications for the expression of disease. Am J Hum Genet 1999;64:1158-65

62 Birky CW. Relaxed and stringent genomes: why cytoplasmic genes don't obey Mendel's laws. J Heredity 1994;85:355-65.

63 't Hart LM, Jansen JJ, Lemkes HHPJ, et al. Heteroplasmy levels of a mitochondrial gene mutation associated with diabetes mellitus decrease in leucocyte DNA upon aging. Hum Mutat 1996;7:193-7.

64 Chinnery PF, Johnson MA, Wardell TM, et al. Epidemiology of pathogenic mitochondrial DNA mutations. Ann Neurol 2000;48: 188-93

65 Howell N. Leber hereditary optic neuropathy: mitochondrial mutations and degeneration of the optic nerve. Vision Res 1997;37:3495-507.

66 Saadati HG, Hsu HY, Heller KB, et al. A histopathologic and morphometric differentiation of nerves in optic nerve hypoplasia and Leber hereditary optic neuropathy. Arch Ophthalmol 1998;1 16:911-16.

67 Newman NJ, Lott MT, Wallace DC. The clinical characteristics of pedigrees of Leber's hereditary optic neuropathy with the 11778 mutation. Am J Ophthalmol 1991;111:750-62.

68 Riordan-Eva P, Sanders MD, Govan GG, et al. The clinical features of Leber's hereditary optic neuropathy defined by the presence of a pathogenic mitochondrial DNA mutation. Brain 1995;1 18:319-37.

69 Man PY, Griffiths PG, Brown DT, et al. The epidemiology of Leber hereditary optic neuropathy in the north East of England. Am J Hum Genet 2003;72:333-9.

70 Torroni A, Huoponen K, Francalacci P, et al. Classification of European mtDNAs from an analysis of three European populations. Genetics $1996 ; 144: 1835-50$

71 Torroni A, Petrozzi M, D'Urbano L, et al. Haplotype and phylogenetic analyses suggest that one European-specific mtDNA background plays a role in the expression of Leber hereditary optic neuropathy by increasing the penetrance of the primary mutations 11778 and 14484. Am J Hum Genet 1997;60:1107-21.

72 Howell N, Kubacka I, Halvorson S, et al. Phylogenetic analysis of the mitochondrial genomes from Leber hereditary optic neuropathy pedigrees. Genetics 1995; 140:285-302.

73 Bu X, Rotter Jl. X chromosomal-linked and mitochondrial gene control of Leber hereditary optic neuropathy: evidence from segregation analysis for dependence on X-chromosome inactivation. Proc Natl Acad Sci USA $1991 ; 88: 8198-202$.

74 Chalmers RM, Davis MB, Sweeney MG, et al. Evidence against an X-linked visual loss susceptibility locus in Leber hereditary optic neuropathy. Am J Hum Genet 1996;59: 103-8.

75 Kerrison JB, Miller NR, Hsu F, et al. A case-control study of tobacco and alcohol consumption in Leber hereditary optic neuropathy. Am J Ophthalmol 2000;130:803-12.

76 Tsao K, Aitken PA, Johns DR. Smoking as an aetiological factor in a pedigree with Leber's hereditary optic neuropathy. Br J Ophthalmol 1999;83:577-81

77 Jenuth JP, Peterson AC, Shoubridge EA. Tissue-specific selection for different mtDNA genotypes in heteroplasmic mice. Nat Genet 1997; 16:93-5

78 Battersby BJ, Shoubridge E. Selection of a mtDNA sequence variant in hepatocytes of heteroplasmic mice is not due to difference in respiratory chain function or efficiency of replication. Hum Mol Genet $2001 ; 10: 2469-79$

79 Battersby BJ, Loredo-Osti JC, Shoubridge EA. Nuclear genetic control of mitochondrial DNA segregation. Nat Genet 2003;33:183-6.

80 Blier PU, Dufresne F, Burton RS. Natural selection and the evolution of mtDNA-encoded peptides: evidence for intergenomic co-adaptation. Trends Genet 2001;17:400-6.

81 Mishmar D, Ruiz-Pesini E, Golik P, et al. Natural selection shaped regional mtDNA variation in humans. Proc Natl Acad Sci U S A 2003;100:171-6

82 Mackey DA, Oostra R-J, Rosenberg T, et al. Primary pathogenic mtDNA mutations in multigeneration pedigrees with Leber hereditary optic neuropathy. Am J Hum Genet 1996;59:481-5.

83 Chinnery PF, Reading PJ, Walls TJ, et al. Recurrent strokes in a 34 year old man. Lancet 1997:350:560.

84 Dubeau F, De Stefano N, Zifkin BG, et al. Oxidative phosphorylation defect in the brains of carriers of the tRNA $A^{\text {leu(UUR) }}$ A3243G mutation in a MELAS pedigree. Ann Neurol 2000;47:179-85.

85 Engel WK, Cunningham CG. Rapid examination of muscle tissue: an improved trichrome stain for fresh-frozen biopsy sections. Neurology 1963;13:919-23. 
86 Old SL, Johnson MA. Methods of microphotometric assay of succinate dehydrogenase and cytochrome coxidase activities for use on human skeletal muscle. Histochem J 1989;21:545-55.

87 Hayashi J, Ohta S, Kikuchi A, et al. Introduction of disease-related mitochondrial DNA deletions into HeLa cells lacking mitochondrial DNA results in mitochondrial dysfunction. Proc Natl Acad Sci USA 1991;88:10614-18

88 Johnson MA, Bindoff LA, Turnbull DM. Cytochrome c oxidase activity in single muscle fibres: assay techniques and diagnostic applications. Ann Neurol 1993:33:28-35.

89 Sasarman F, Karpati G, Shoubridge EA. Nuclear genetic control of mitochondrial translation in skeletal muscle revealed in patients with mitochondrial myopathy. Hum Mol Genet 2002;11:1669-81.

90 Taivassalo T, Abbott $A$, Wyrick $P$, et al. Venous oxygen levels during aerobic forearm exercise: an index of impaired oxidative metabolism in mitochondrial myopathy. Ann Neurol 2002;51:38-44.

91 Argov Z, Bank W. Phosphorus magnetic resonance spectroscopy (31-P MRS) in Neuromuscular disorders. Ann Neurol 1991;30:90-7.

92 van Beekvelt MC, van Engelen BG, Wevers RA, et al. Quantitative near-infrared spectroscopy discriminates between mitochondria myopathies and normal muscle. Ann Neurol 1999:46:667-70.

93 Moraes CT, Schon EA. Detection and analysis of mitochondrial DNA and RNA in muscle by in situ hybridization and single-fiber PCR. Methods Enzymol 1996:264:522-40.

94 Thorburn DR, Dahl HHM. Mitochondrial disorders: genetics, counseling, prenatal diagnosis and reproductive options. Am J Med Genet 2001;106:102-14

95 Poulton J, Turnbull DM. 74th ENMC International workshop: mitochondrial diseases. Neuromuscul Disord 2000:10:460-2.
96 Chinnery PF, Turnbull DM. The epidemiology and treatment of mitochondrial disease. Am J Med Genet 2001;106:94-101.

97 Fu K, Hartien R, Johns T, et al. A novel heteroplasmic tRNA ${ }^{\text {lev(UUR) }}$ mtDNA point mutation in a sporadic patient with mitochondrial encephalomyopathy segregates rapidly in muscle and suggests an approach to therapy. Hum Mol Genet 1996;5:1835-40.

98 Clark K, Bindoff LA, Lightowlers RN, et al. Correction of a mitochondrial DNA defect in human skeletal muscle. Nat Genet 1997;16:222-4.

99 Taivassalo T, Fu K, Johns T, et al. Gene shifting: a novel therapy for mitochondrial myopathy. Hum Mol Genet 1999;8:1047-52.

100 Taivassalo T, Matthews PM, De Stefano N, et al. Combined aerobic training and dichloracetate improve exercise capacity and indices on aerobic metabolism in muscle cytochrome oxidase deficiency. Neurology 1996;47:529-34

101 Taivassalo T, Shoubridge EA, Chen J, et al. Aerobic conditioning in patients with mitochondrial myopathies: physiological, biochemical, and genetic effects. Ann Neurol 2001:50:133-41.

102 Taylor RW, Chinnery PF, Turnbull DM, et al. Selective inhibition of mutant human mitochondrial DNA replication in vitro by peptide nucleic acids. Nat Genet 1997;15:212-15.

103 Chinnery PF, Taylor RW, Diekert K, et al. Peptide nucleic acid delivery into human mitochondria. Gene Ther 1999;6:1919-28

104 Manfredi G, Gupta N, Vazquez-Memije ME, et al. Oligomycin induces a decrease in the cellular content of a pathogenic mutation in the human mitochondrial ATPase6 gene. J Biol Chem 1999;274:9386-91.

105 Inoue K, Nakada K, Ogura A, et al. Generation of mice with mitochondrial dysfunction by introducing mouse mtDNA carrying a deletion into zygotes [In Process citation]. Nat Genet 2000;26:176-81.

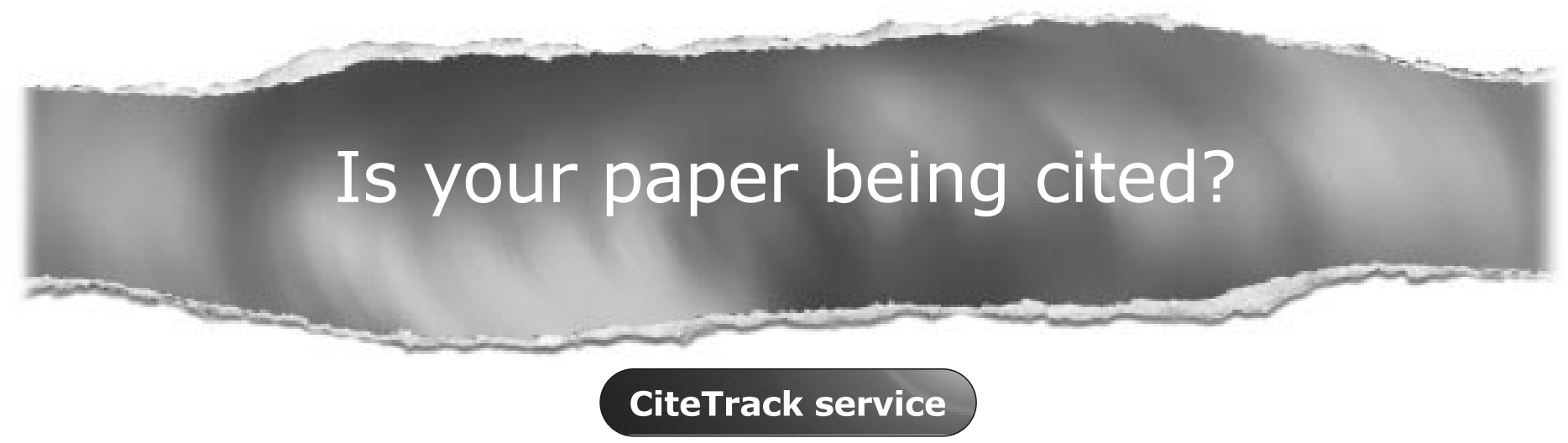

CiteTrack will alert you by email whenever new content in the Journal of Neurology, Neurosurgery, and Psychiatry or a participating journal is published that matches criteria you want to track Topics: Tell CiteTrack which words or subjects to watch for in new content Authors: Be alerted whenever key authors you are following publish a new paper Articles: Know whenever a paper of interest to you is referenced by another paper

\section{www.jnnp.com}

